\title{
The Concept of Sanctification in the Book of Leviticus: A Study of Leviticus 11 and 20
}

\author{
Milton T. Pardosia
}

\begin{abstract}
Through the book of Leviticus, people will understand the fundamental principles of faith and how to maintain their life to be holy. There are two ideas of sanctification in the book of Leviticus. The first is sanctification which relates to ceremonial laws (purification), the other is sanctification itself. In this idea, there are two things that must be understood: First, sanctification is called "the way" if it is related to ceremonial laws [sacrificial of blood (almost like purification)]; the other, sanctification is a "progressive work" if it is related to obedience to God's commands. There is a relationship between Lev. 11 and Lev. 20. Both have Hithpael stem (Lev. 11: 44, 45 and 20: 7) and Lev. 11: 44-45 is summarized in Lev. 20: 25-26. The verb qādāš (qadas) or qādēš (qades) in Hithpael stem can be translated as "sanctify yourselves" or "you shall make yourselves holy". God asked Israelites to sanctify themselves in two things: doing ceremonial laws (because of sins or when they come to God) and keeping God's laws. In the case of Lev. 11 and 20, God asked Israelites to sanctify themselves by keeping His laws as a sign that they have been sanctified by God.
\end{abstract}

Keywords

Purification, sanctification, obedience

Sanctification is not only a doctrine of New Testament but also a doctrine of Old Testament for "It is God's will that we should be sanctified"1 (I Thess. 4: 3). Moreover, sanctification itself is the second stage ${ }^{2}$ in the Christian experience of salvation. Therefore, by receiving this gift, God wants His people to respond it as their responsibility upon the blessing ${ }^{3}$.

The word "sanctify" or "sanctification" is derived from Latin words sanctus (holy) and facere (to make). In other words, the word "sanctify" means to make something or someone become holy. In Hebrew language, the verb "sanctify" is qādās (qadas) or $q \bar{a} d \bar{e} s ̌$ (qades). This verb has some meanings and cannot be translated to all texts in the Old Testament by using the same meaning. However, the verb qāāas or qāaēs is not only used in Qal stem but also in Niphal, Piel, Hiphil, and Hithpael stems.

\section{STATEMENT OF THE PROBLEM}

There is a contrast meaning in using the verb $q \bar{a} d \bar{a} s ̌$ or $q \bar{a} d \bar{e} s ̌$ in Hithpael stem especially in Lev. 11: 44, 45 and 20: 7 with other stems, since in most translations, this stem is translated as "reflexive". Some versions of the Bible translate this verb as "consecrate yourselves" (New International Version), or "sanctify yourselves" (King James Version).

The question is about the meaning of the verb $q \bar{a} d \bar{a} s ̌$ or $q \bar{a} d \bar{e} \bar{s}$ in Hithpael stem in those two texts. If

\footnotetext{
aUniversitas Advent Indonesia, Indonesia

Correspondent Author:

Milton T. Pardosi, Kampus Universitas Advent Indonesia, Jln. Kolonel Masturi No. 288, Parongpong, Bandung, West Java, Indonesia

E-mail: mtpardosi@gmail.com
} 
this verb is translated as "sanctify yourselves", then, is there any relation to the doctrine of sanctification? And if the answer is yes, how did Israelites sanctify themselves? Or for today, can men sanctify themselves?

\section{PURPOSE OF THE STUDY}

The purpose of this study is to determine the meaning of the verb qādāš or qādēš in Hithpael stem in Lev. 11: 44, 45 and 20: 7. The other is to find out whether there is any relationship between those texts with the doctrine of sanctification.

\section{LIMITATION AND DELIMITATION}

This study is confined to the meaning of the verb $q \bar{a} d \bar{a} \bar{s}$ or qādēš in Hithpael stem in Lev. 11:44, 45 and 20: 7 which are related to the doctrine of sanctification as the purpose of this study. Moreover, this study would not discuss all the details of the laws in those chapters.

\section{METHODOLOGY}

This study applies the grammatical-biblical method of exegesis to solve the problems that were being undertaken. The immediate context in Lev. 11: 44, 45 and 20: 7 and the larger context of chapters 11 and 20 will be examined. In other way, this study also applies a way of systematic theology to relate those texts to the doctrine of sanctification. The Bible excels as the primary source. Secondary sources include theological dictionaries, concordance, lexicons, grammars, and commentaries.

The first part is introduction. It contains statement of the problem, purpose of the study, limitations and delimitations, and methodology. The following part introduces sanctification in the book of Leviticus. It contains themes of Leviticus and ideas of sanctification in Leviticus. The next part explains the context of Lev. 11: 44, 45 and 20: 7. It includes literary analysis and theological analysis of Lev. 11: 44, 45 and 20: 7. The fourth part focuses on the Hebrew verb qāāaš or qādēš. It includes the stems

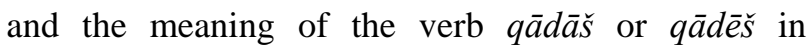
Hithpael stem and the translation of Lev. 11: 44, 45 and 20: 7. And the last part includes summary of the results of the research and the conclusion of the study.

\section{SANCTIFICATION IN THE BOOK OF LEVITICUS}

Leviticus lies "at the heart of the Pentateuch" "the Gospel of the Old Testament". The reason is because "It contains all the fundamentals principles of our religion"7. Furthermore, "The book of Leviticus is filled with instructions concerning how to maintain the holy space that was set apart for God's presence" ${ }^{\text {. }}$.

\section{Theme of Leviticus}

In the book of Leviticus, there is a word which is repeated many times as a keyword. The word is "holiness". The book of Leviticus has 27 chapters and about 859 verses. The word "holy" or "holiness"10 appears 90 times in Leviticus. In all Pentateuch, however, it appears 176 times $^{11}$. It means this word appears more than $50 \%$ in Leviticus and 86 times appear in other books of Pentateuch.

In Leviticus, there are some phrases which replied many times as key thoughts. First, "I am the LORD (Yahweh) your God or their God (only in Lev. 26: 44 using 'their God')" appears 23 times in Leviticus ${ }^{12}$. The next one is "I am Holy"13. The third is "I am the LORD your God who brought you up out or out of Egypt $^{\text {"14 }}$. This last phrase is same with the phrase in Exod. 20: 2 as the prologue of the Ten Commandments.

In his book, Turnbull mentions that the book of Leviticus can be called as the book of Laws of the 
Covenant Theocracy which divided in two parts. The first is Law of Approach to God (chs. 1-16) and the second is Laws of Communion with God (chs. $17-27)^{15}$.

In his explanation about those laws, Turnbull concludes that "Only a holy people can come into God's presence and that only a holy people can live in communion with God" ${ }^{\text {"16 }}$. In other words, the theme of the book of Leviticus is how Israel (in the past) to be holy and keep holy in her relationship with God for God had sanctified her as a holy nation. At the same time, how His church (in the present) to be holy and keep holy for God has sanctified His church as taught in the New Testament.

\section{Ideas of Sanctification in Leviticus}

In the book of Leviticus, there are two ideas about sanctification. These two ideas use the same verb in Hebrew language but have different meanings according to the text itself or the context.

The first idea is sanctification which is called purification or consecration. The purpose is to consecrate or to separate something for God's purpose; or to purify the body after doing sin; or to prepare oneself before approaching something sacred or event or festivals. This idea is related with the ceremonial laws or rituals. The concept is to make unclean become clean by a process of cleansing ${ }^{17}$.

The second idea is sanctification itself. This idea is also related with the ceremonial laws. In this idea, the purpose is how to make clean become holy.

The problem of these two ideas is that both of them have ceremonial laws, rituals, or a sacrificial blood. So, it is difficult to distinguish which one either purification (consecration) or sanctification without looking on the context. Anyway, these two ideas can be called as "the way" to make unclean (anyone or anything) become clean (purification or consecration) and to make clean become holy (sanctification).

But in the case of sanctification itself, there are two important things that must be known. The first, sanctification will be called "the way" if it requires sacrificial blood or ceremonial laws. The second, sanctification is "a progressive work" related to the ceremonial laws but to obedience or keeping God's commandments. It is a process to achieve moral and spiritual qualities in relation with God.

At that time, Israel was asked to keep God's laws as a process to keep them holy for God had sanctified them as a holy nation (Exod. 19: 5, 6). In this sense, Leviticus stresses that "There are two aspects of sanctification, a divine act and human actions. God sanctifies and man also sanctifies"19. In other words, God sanctifies His people as the second stage of His plan to save human beings, and after it, those who have been sanctified need to keep their life holy through obedience to the laws as Paul mentions that "Sanctification is expressed through obedience to the standard of teaching (Romans 6: 17-19) just as in Leviticus through obedience to the law"20.

In the New Testament, sanctification is also a process and not a moment like "salvation itself-according to the use of the term in Scripture (2 Tim. 1: 9, salvation in the past; Phil. 2: 12, salvation in the present; Romans 13: 11, salvation in the future) and in the actual history of the redeemed-so sanctification must be considered under its three tenses”21. Arthur W. Pink explains the process of sanctification itself in three tenses: (1) Present Perfect Continues: we have been sanctified (Jude 1; Heb. 10: 10; 2 Thess. 2: 13); (2) Present Tense: we are daily being sanctified (2 Cor. 4: 16; 7: 1; 1 Thess. 5: 23); and (3) Future Tense: the Christian's (complete) sanctification is yet future (Romans 8: 20; Heb. 12: 23; 1 John 3: 2) 22 .

Most of the ceremonial laws (purification) and sacrificial blood in the Pentateuch are symbols of Jesus Christ who died as the Savior. But, by His death, men do not need to sacrifice something to purify or to sanctify themselves. So, in the New Testament, "the way" of purification and sanctification ${ }^{23}$ were 
canceled by the blood of Jesus. And now, only "the process" of sanctification is being continued ${ }^{24}$.

Finally, the process of sanctification in the book of Leviticus is a cooperative-work between God and man. Without this cooperative-work, sanctification from God is useless and nothing since God required something from Israelites to be done as their responsibilities. In other words, God sanctified Israel and $\mathrm{He}$ offered "the way" of purification or sanctification to her to solve her problem in sin, then she could become clean or holy. And the next step was to obey His commandments (laws), as a process in order that she would be able to keep her life holy as God is holy.

\section{THE CONTEXT OF LEVITICUS 11: 44, 45 AND 20: 7}

This section discusses about the context of Lev. 11: 44, 45 and 20: 7 as the main points in this study. But before come to those texts, it is good to know the historical background of Leviticus itself as an introduction to those texts.

As the book of Worship ${ }^{25}$, Leviticus is the continuation of Exodus. The book itself "covers a period of but 30 days" 26 . This period was started from "...the first month in the second year, on the first day of the month, that the tabernacle was reared up" (Exod. 40: 17), until "...on the first day of the second month, in the second year after they were come out of the land of Egypt” (Num. 1: 1).

In Exodus, God spoke to Israel from the mount, but after the Tabernacle was reared up and God's glory has descended upon it, now, God speaks from the Tabernacle to Moses, Aaron, his sons (priests), Levites and His people as a congregation ${ }^{27}$.

The purpose of the book itself is to "preserve divine sermons for the instruction of the congregation in cultic and ethical matters" ${ }^{28}$. From these two parts, the whole book of Leviticus can be divided into six divisions ${ }^{29}$.
(1) Regulation for Sacrifices (1: 1-7: 38);

(2) Ordination of the Priest and the First Sacrifices at the Tent of Meeting (8: 1-10: 20);

(3) Laws on Ritual Purity (11: 1-15: 32);

(4) Regulation for the Day of Atonement (16: 1-34);

(5) Laws and Holy Living (17: 1-26: 46);

(6) Laws on Tithes and offerings (27: 1-34).

Moreover, there are two verses in Leviticus which are important to be consideres for they have double functions. The first one is Lev $1: 1-2$ as the introduction not only for the first speech of the book but for the whole book. The other one is Lev 26: 46 as a conclusion both the laws on holy living and the entire book ${ }^{30}$.

\section{Literary Analysis}

The first part is Lev. 11: 44, 45. As mentioned above that Leviticus $11^{31}$ belongs to the third division of Leviticus (chs. 11-15). This division is about Laws on Ritual Purity. Those chapters are:

(1) Clean and unclean foods and animals (11);

(2) The giving of birth (12);

(3) Leprous growth on people, contaminated garments and houses (13-14);

(4) Discharges from the genitals (15).

But, in chapter 11, there is no indication about how men can purify themselves if they eat the unclean animals (ritual purity). This chapter is only about the characteristics of the clean and unclean animals, and pollution by animals and its treatment.

Moreover, this chapter is a part of laws in chapter 20. It is not only a law of ritual purity as Wenham says, but it is also a part of Laws and Holy Living ${ }^{32}$. The key text is in Lev. 20: 25-26 when God said to Moses, "Ye shall therefore put difference between clean beasts and unclean; and between unclean fowls and clean; and ye shall not make your souls abominable by beast, or by fowl, or by any manner of living thing that creepeth on the ground, which I have separated from you as unclean..." 
The second part is Lev. 20: $7^{33}$. This chapter belongs to Laws and Holy Living (chs. 17-26). Chapter 20 contains laws with penalties for sacrifices to Molech, sorcery, sexual offenses, and clean and unclean animals. Wenham ${ }^{34}$ divides it as chiastic where:

vv. 1-2a as the introduction:

vv. 2b-6 Sin Against Religion (A)

vv. 7-8 Exhortation to Holiness (B)

vv. 9-21 Sins Against Family (C)

vv. 22-26 Exhortation to Holiness (B')

vv. 27 Sins Against Religion (A')

Through the explanation of literary analysis of Lev. 11 and 20, one conclusion can be drawn that both of them are related to each other since Lev. $11: 1-47$ is summarized in Lev. 20: 25-26. It is also proved by checking the stem of the verb in both texts. Both of them uses hithpael stem. The other indication is a chiastic form (ABBA) by combining those texts. The form is:

Leviticus 11: 44, 45

I am the Lord your God (A)

Sanctify yourselves (b)

(B)

Be holy (c)

Leviticus 20: 7

Sanctify yourselves (b')

(B')

Be Holy (c')

I am the Lord your God (A')

\section{Theological Analysis}

There are many doctrines can be found in Leviticus 11 and 20 that can be combined as unison. But, in this study, only some of them will be discussed. The first one is about Dietary Law ${ }^{35}$ (Lev. 11: 1-47 and 20: 25, 26).

This law is started at first when God gave this law to Noah and his family (Gen. 7: 2 and 9: 3, 4). At that time, there is no explanation or statement like in Lev. 11 about what kind of animals that they could eat. But in Gen. 7: 2, God distinguished only between clean and unclean animals that came into the ark. This was the only sign for Noah about clean and unclean animals. Through this sign, Noah could know which one is clean and unclean by looking their numbers. Because God said that "of every clean beast thou shalt take to thee by sevens, the male and female: and of beast that are not clean by two, the male and his female" (Gen. 7: 2).

God did this separation for He knew that after the flood, Noah and his family would not have food because all plants would be destroyed. In other words, after the flood, Noah and his family must eat meat (clean animals).

For Israel, Dietary Law is a law in which they must keep and follow it as the sign that they were the people of God. This is because God had chosen and sanctified them as His mine ${ }^{36}$.

How does Moses relate between food and holiness? Is there any hint that Moses gives to relate both of them? Victor P. Hamilton mentions in his book that "It is no accident that every time food regulations appear in the Pentateuch, the word holy is not far

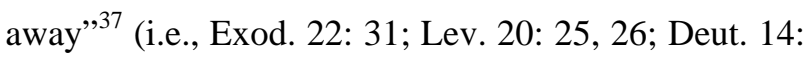
21, etc.). It means that food and holiness are related to each other.

This law is not a symbol of Jesus' death since there is no shedding blood on it or ceremonial but a law to keep their life holy before God. All laws which are symbols of Jesus are canceled when Jesus died. For instance: law of purification (waters, etc.), and sacrificial law or shedding blood. These laws are called ceremonial laws. By doing sacrifice of animals, Israel came to God to ask forgiveness of her sins. In other words, because Dietary Law is not a ceremonial $\mathrm{law}^{38}$, then, it is valid until today since this law is not a symbol of Jesus' death ${ }^{39}$.

The second one is doctrine of God. In Lev. 11: 44-45 and 20: 7-8, 24, 26, God mentions Himself as God of Israel and He is holy. At the same time, God is the one who had sanctified Israel to be His mine. It 
means that God is the one who has the initiative to separate Israel from other nations to be His holy nation. So, as her God, God does not want if Israel has other gods and worship them as stated in Lev. 20: 1-6, 27. This is same with the first commandment in Exod. 20: 3: "You shall have no other gods before me". In other words, Lev. 20: 1-6 is an implication of the first commandment of the Decalogue.

In other side, as God who has sanctified, He has right to give laws to His people. The purpose is to keep His people's life holy and not to limit their life. By giving laws, God is providing the way in which humankind can get benefit from it since sanctification itself is a process of keeping His Laws. Sanctification without law is nothing, and obedience without law is also nothing as James mentions in James 2: 26 that "...faith without works is dead also"

The next one is holiness ${ }^{41}$. This teaching is the goal of the doctrine of sanctification. All laws that have been written on those chapters are laws in which Israel must obey to keep her life holy ${ }^{42}$.

As mentioned above that most of those laws are related to the Ten Commandments in Exod. 20: 3-17. For instances:

$$
\begin{array}{lc}
\text { Leviticus } 20 & \text { Exodus } 20 \\
\text { vv. 1-5 (Molech) } & \text { v. } 2 \text { (Other gods) } \\
\text { v. 6, 27 (Sorcery) } & \text { v. } 2 \text { (Other gods) } \\
\text { v. } 9 \text { (Curses his parents) } & \text { v. } 12 \text { (Honor } \\
& \text { your parents) } \\
\text { v. 10-21 (Sexual offenses) } & \text { v. } 14 \text { (Adultery) }
\end{array}
$$

The conclusion is that all laws in chs. 11 and 20 are still valid as Decalogue is also valid until today, because they are not a symbol of Jesus' death.

\section{THE HEBREW VERB $Q \bar{A} D \bar{A} \bar{S}$ OR $Q \bar{A} D \bar{D} \check{S}$}

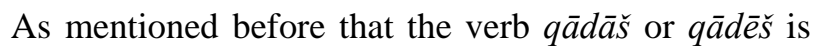
not only used in Qal stem but also in Niphal, Piel, Hiphil, and Hithpael stems. It is important to know the meaning of this verb when used in those stems especially in Hithpael stem.

\section{Stems of Qādāš or Qādēš in the Old Testament}

In this section, only examples of verses in the Bible for each stem would be given. The first one is in Qal stem. In Qal stem, "It connotes the state of that which belongs to the sphere of the sacred. Thus such a subject is in a state distinct from the common or profane” ${ }^{43}$. The second one is Niphal stem. In Niphal stem, "Yahweh is repeatedly said 'to be sanctified' (KJV) or 'to show Himself holy' (NIV)" (Num. 20: 13; Isa. 5: 16; Ezek. 20: 41; 28: 22, 25; 38: 16; 39: 27; 36: $23)^{44}$. The next one is Piel stem. The Piel stem is used,

To express the sanctification or consecration of various objects: Sabbath (Gen. 2: 3), firstborn males (Exod. 13: 2), the people of Israel (Exod. 19: 10, 14), Aaron and his sons (Exod. 28: 41; 29: 33, 44), the Levites (2 Chron. 29: 5), the tabernacle (Exod. 29: 44; 30: 29), the altar and its furnishings (Exod. 29: 36-37), the temple (2 Chron. 29: 5, 17), a fast (Joel 1: 14; 2: 15), and the like ${ }^{45}$.

The fourth one is Hiphil stem. The Hiphil "has the sense of dedication, not with the implication of cultic qualification, but rather of transfer to the possession of God, to whom the person or thing dedicated now exclusively belongs. The Hiphil focuses on the process of dedication" ${ }^{46}$.

\section{The Meaning of Qādāš or Qādēš in Hithpael Stem}

In Hithpael stem, the verb Qādāš or Qādēš means "denotes the entering of a state of holiness through one's own fault. In this case, nothing more than cultic qualification is implied. A person consecrated himself when he had been temporarily excluded from the life of the community by uncleanness, or when he came into contact with God”, ${ }^{\text {, }}$.

But in Lev. 11: 44 and 20: $7^{48}$, the people of Israel were called to sanctify themselves which is not related to the cultic law. God asked them to sanctify themselves by keeping His commandments ${ }^{49}$. It is different with "sanctify yourselves" when related to ceremonial laws ${ }^{50}$. 
Translations of Leviticus 11: 44, 45 and 20: 7

Leviticus 11: 44, $45^{51}$.

v. 44 For I am Yahweh your God, you shall make yourselves holy so that you will be holy, for I am holy and never defile yourselves with any swarming thing that crawl upon the earth.

v. 45 For I am Yahweh who brought you up out of the land of Egypt to be your God, you shall therefore be holy, for I am holy.

Leviticus 20: 7.

v. 20 You shall make yourselves holy so that you will be holy for I am Yahweh your God.

The phrase "You shall make yourselves holy so that you will be holy"52 explains that sanctification is also man's task and not only God's task. Sanctification from God is useless if human beings do not do their part.

\section{CONCLUSIONS}

Sanctification as the second stage in the experience of salvation is taught also in the Old Testament as in the New Testament. In this stage, God and human beings are working together. God sanctifies men and men response it by keeping their life holy (cooperative-work).

\section{Summary}

The book of Leviticus is an important book for through this book, men will understand the fundamentals principles of faith (laws) and how to maintain their life keep holy (rituals and laws) because God has sanctified them.

The theme of the book itself is "Holiness". God has sanctified Israel, therefore, she must keep her life holy, because God is holy.

There are two ideas of sanctification in the book of Leviticus. The first one is sanctification is related to ceremonial laws (purification). The point is to make unclean become clean by cleansing. The second one is sanctification itself. This idea is also related to ceremonial laws. In this idea, the purpose is how to make clean become holy.

In sanctification itself, there are two things that must be understood. The first one, sanctification is called "the way" if it is related to ceremonial laws or sacrificial blood (almost like purification). The second one, sanctification is a "progressive work" if it is not related with rituals but related with obedience to God's commandments. The goal is to be holy (heart, mind, body).

In the New Testament, sanctification is also a process of keeping God's laws. In Old Testament, there are two kinds of sanctification: "the way" (ceremonial laws) and "a process” (obedience). In the New Testament, "the way" has been abolished by the death of Jesus since ceremonial laws in the Old Testament are symbol of Jesus death.

There is a relationship between Lev. 11 and Lev. 20. Both of them have Hithpael stem (Lev. 11: 44, 45 and 20: 7), and Lev. 11: 44-45 is summarized in Lev. 20: 25-26. Moreover, most of laws in Lev. 20 are related to the Ten Commandments in Exod. 20: 3-17.

The verb qādāš or qādēš in Hithpael stem can be translated as "sanctify yourselves" or "you shall make yourselves holy" (counterpart of Piel stem). God asked Israelites to sanctify themselves in two things: doing ceremonial laws (because sins or when come to God) or keeping God's laws. In the case of Lev. 11 and 20, God asked Israelites to sanctify themselves by keeping His laws as a sign that they were different from other nations. They had been sanctified by God, then, they must keep holy.

\section{Conclusion}

Sanctification is a process like salvation itself is also a process. It does not mean that if someone has been sanctified, he or she will be holy until the end of time or until the person dies although he or she does not obey God's commandment. 
Finally, Lev. 20: 7 is as important as Lev. 11: 44, 45 in the doctrine of sanctification. This is because they have the verb qāā̄s or qādēs in Hithpael stem and followed with laws. If this verb is followed by laws or commandments, then, it means man must keep God's commandments (a process of sanctification). But if this verb is followed by ceremonial laws (rituals), then, it means human man must sanctify themselves by doing ceremonial laws (because of sins or to come to God).

\section{Notes}

1. Daniel T. Bourdeau, Sanctification or Living Holiness (Battle Creek, Michigan: Steam, 1964), 5.

2. W. E. Sangster, The Path to Perfection: An Examination \& Restatement of John Wesley's Doctrine of Christian Perfection (London: Epworth, 1943), 27-28. For John Wesley, the first stage "consisted of justification and sanctification; the former being a change in our relations with God, our pardon and reconciliation”. In this stage, “A new heart is given to us, so that we now love God and desire to please Him, and will not willingly sin against Him in anything". The second stage is "entire sanctification, which comes as an immediate gift of God, entirely cleansing the heart from sin and 'slaying the dire root and seed' of it” (I Thess. 5: 23, 24). Ibid.

3. J. Rodman Williams, Renewal Theology: Salvation, the Holy Spirit, and Christian Living (Grand Rapids: Zondervan, 1990), 2: 102. "Sanctification is also the task of man. God does not work without our involvement. It is, rather, God all the way through man all the way”.

4. James Leo Garrett, Jr., Systematic Theology: Biblical, Historical, and Evangelical (Grand Rapids: Eerdmans, 1995), 2: 356.

5. Leslie Hardinge, Leviticus: Christ Is All (Boise, Idaho: Pacific, 1988), 5. "And without it the ministry of Christ would be shrouded in mystery". Ibid.

6. M. Ryerson Turnbull, Studying of the Book of Leviticus (Virginia: Presbyterian Committee of Publications, 1926), 10.

7. Ibid., 9-10. This book teaches us about the relation between Old Testament and New Testament. It teaches about Jesus and the cross, holiness, the mercy and God's grace. "Leviticus is that it presents the truth in a pictorial way, in object-lessons”. Ibid.

8. John H. Walton and Victor H. Matthews, Genesis-Deuteronomy: The IVP Bible Background
Commentary (Illinois: InterVarsity, 1997), 142. These instructions are cultic laws and moral laws.

9. John H. Sailhamer, The Pentateuch as Narrative (Grand Rapids: Zondervan, 1992), 323. The central theme of the book is holiness. The book intends to show how Israel was to fulfill its covenant responsibility to be "a kingdom of priests and a holy nation” (Exod. 19: 6; Lev. 26: 5).

10. W. H. Griffith Thomas, Through the Pentateuch Chapter by Chapter (Grand Rapids: Eerdmans, 1957), 108. “The keynote of the book is 'Holiness', in its primary meaning of separation, which includes separation from evil and separation to God”. The word holy in English Dictionary means "specially, recognized as or declared sacred by religious use or authority; consecrated; dedicated or devoted to the service of God, the church, or religion; holy refers to the divine, that which has its sanctification directly from God or is connected with Him”. Random House Dictionary of the English Language, 2nd ed. (1987), s.v. "Holy."

11. Robert Young, Analytical Concordance to the Holy Bible, 8th ed., s.v. "Holy".

12. Young, s.v. “God.” Lev. 11: 44; 18: 2, 4, 30; 19: 2, 3, 4, 10 , 25, 31, 34, 36; 20: 7, 24; 23: 22, 43; 24: 22; 25: 17; 25: 38, 55; 26: 13, 44, 45 (verses 45: I might be their God).

13. Lev. 11: 44, 45; 19: 2; 20: 26; $21: 8$.

14. Lev. 11: 45; 22: 33; 25: 38; 26: 13.

15. Turnbull, 13.

16. Turnbull, 15.

17. Gordon J. Wenham, The Book of Leviticus, New International Commentary on the Old Testament (NICOT) (Grand Rapids: Eerdmans, 1979), 18-20. I.e., Lev. 8; 11: 25, 28; $12 ; 13 ; 14: 8$, 9; 15 , etc.

18. Bourdeau, 8.

19. Wenham, 22-3. "Keeping the law is indeed one of the most important duties of the people of Israel if they are to demonstrate holiness” (Lev. 19: 2; 20: 7; Num. 15: 39).

20. Ibid., 25.

21. Arthur W. Pink, The Doctrine of Sanctification (Swengel, PA: Reiner, 1975), 85.

22. Arthur W. Pink, The Doctrine of Sanctification (Swengel, PA: Reiner, 1975), 85.

23. Ibid., 16-17. Definitions of sanctification are: (1) in sanctification, something is actually imparted to us; (2) sanctification is principally a work wrought in us; (3) sanctification cleanses from pollution; (4) sanctification is a moral work, by which the sinner is made holy; (5) sanctification is a freedom from the tyranny of sin, into the liberty of righteousness; and (6) sanctification is that work of the Spirit whereby we are fitted to be worshippers of God. Ibid.

24. Louis Berkhof, Systematic Theology (Grand Rapids: 
Eerdmans, 1948), 533-534. "It affects the whole man: body and soul; intellect, affections and will”. Ibid.

25. W. G. Heslop, Lesson From Leviticus (Grand Rapids: Kregel, 1975), viii. "Leviticus is the book of Worship. Worship the Lord in the beauty of Holiness is the message of Leviticus. Exodus is the book of redemption”. These two books have a relationship to each other. After God redeemed Israel by the blood of the lamb (Exodus) as His holy nation, now Israel must worship Him in the beauty of holiness (Leviticus).

26. "Leviticus: Introduction”, The Seventh-day Adventist Bible Commentary ( $S D A B C$ ), ed. Francis D. Nichol (Washington, D.C.: Review \& Herald, 1953), 1: 693.

27. "Leviticus: Introduction", The Seventh-day Adventist Bible Commentary (SDABC), ed. Francis D. Nichol (Washington, D.C.: Review \& Herald, 1953), 1:694.

28. John E. Hartley, Leviticus, Word Biblical Commentary (WBC), Vol. 4 (Dallas, Texas: Word, 1992), 32. Chs. 1-17 are cultic laws and the moral laws are in chs. 18-27.

29. John E. Hartley, Leviticus, Word Biblical Commentary (WBC), Vol. 4 (Dallas, Texas: Word, 1992), 34.

30. John E. Hartley, Leviticus, Word Biblical Commentary (WBC), Vol. 4 (Dallas, Texas: Word, 1992), 30. See the explanation of ch. 27. Lev. 27: 34 is also function as the summary.

31. Wenham, 161. "Chapter 11 opens a new section of the book of Leviticus. Chs. 11-15 deal with various kinds of uncleanness and how men may be cleansed from them”.

32. Hartley, 139. Compare to Lev. 11: 43-45.

33. Jacob Milgrom, Leviticus 17-22, Anchor Bible (AB), Vol. 3A (Garden City, NY: Doubleday, 2000), 1739. "Vv. 7-8 should also be regarded as a bridge, connecting the two seductive practices that perpetually threaten to assimilate Israel with its neighbors: idolatry and sexual license”. Ibid.

34. Wenham, 276.

35. Lev. 11: 1-8 (Land creatures); 11: 9-12 (Water creatures); 11: 13-23 (Flying creatures); 11: 24-47 (Pollution by animals and its treatment). This prohibition is permanent. It is shown by using negative word $l \bar{o}$ ' and not 'al (Immediately prohibition). See Lev. 11: 44 and 20: 25. Both of them use $l \bar{o}$ ' (permanent).

36. Read Lev. 20: 23. This is a sign that Israel is different from other nations.

37. Victor P. Hamilton, Handbook on the Pentateuch (Grand Rapids: Baker, 1982), 276.

38. George W. Reid, "Health and Healing”, The Seventh-Day Adventist Bible Commentary (SDABC), ed. George W. Reid (Washington, D.C.: Review \& Herald, 2000), 12:774-6. See the explanation of dietary law and its validity.

39. Peter who lived after Jesus died did not want to eat unclean animals even God Himself asked him to eat them (Acts
10:9-16). This is a sign that although Jesus has died, Dietary Law is still valid.

40. “Supplementary Material”, SDABC, 7: 908. “True sanctification will be evidenced by a conscientious regard for all the commandments of God... (R\&H Oct. 5, 1886)”. "Those who dishonor God by transgressing His law may talk sanctification, but it is of that value, and just as acceptable, as was the offering of Cain. Obedience to all the commandments of God is the only true sign of sanctification. Disobedience is the sign of disloyalty and apostasy (MS 41, 1897)”. Ibid.

41. Miroslav M. Kiš, "Christian Lifestyle and Behavior”, The Seventh-Day Adventist Bible Commentary (SDABC), ed. George W. Reid (Washington, D.C.: Review \& Herald, 2000), 12:683-4. "The call to holiness is an invitation to a life that is separate from passions, fashions, and sinful ways. It is a call to come out, to be separate (Is. 52: 11; 2 Cor. 6: 14-18), to escape the influences of the world... In His call to holiness, God invites humans to a life of moral purity”. Ibid.

42. Milgrom, 1740. "Holiness for Israel is achieved by following God's commandments". This is not only for Israelites but also for priests. Priests and Israelites must obey God's commandments and must beware lest they become "impure". For examples: dietary law is a law to keep their body holy; the laws of religion and family are the law to keep their relationship with God and humans holy. The point is for God had sanctified Israel, then, they must keep holy by keeping His commandments.

43. Jackie A. Naude, “qdš”, New International Dictionary of Old Testament Theology \& Exegesis (NIDOTTE), ed. Willem A. VanGemeren (Grand Rapids: Zondervan, 1997), 3:883. See the explanation of Qal. For instances: Exod. 29: 21; Num. 16: 37, 38; Lev. 6: 18; Exod. 29: 37; 30: 29, etc.

44. Garrett, 356.

45. Garrett, 356.

46. Naude, 885-886. See the explanation of Hiphil stem. For examples: Lev. 27:14, 15; Lev. 27: 16-19, 22, etc.

47. Ibid. For examples: Bathsheba (2 Sam. 11: 4), priests and Levites (Exod. 19: 22; 1 Chron. 15: 12, 14; etc.), Jesse and his sons (1 Sam. 16: 5), etc.

48. John Joseph Owens, Analytical Key to the Old Testament, Vol. 1, Genesis-Joshua (Grand Rapids: Baker, 1990), 475, 520. The parsing of this verb in Lev. 11: 44 and 20: 7 is same (hithpael, perf., 2 masc., plural + waw consecutive). So it can be translated as imperfect. The next word after it is parsed as Qal, perf., 2 masc., plural + waw consecutive. It can be translated as imperfect also.

49. Milgrom, 1739-1740. See the explanation of v. 7. compare to Ezek. 38: 23. "All other occurrences of this Hitphael are nonpriestly, where the meaning is different, namely, 'purify 
oneself' (Vol. 1. 965-967)”. The one exception is Ezek. 38: 23. "Israel makes itself holy by obeying YHWH's commandments, YHWH makes himself holy by his might-in this instance, by his devastation of Gog”. Ibid.

50. Garret, 357. Sanctify yourselves "in view of a forthcoming event (Num. 11: 18; Josh 3: 5; 7: 13), Levites, priests, both Levites and priests, priests families are commanded to consecrate themselves ceremonially, while Yahweh shows his own holiness" (2 Chron. 29: 5; Exod. 19: 22, 1 Chron. 15: 12, 14; 2 Chron. 31: 18; Ezek. 38: 23). Garret considers that "no text in the Old Testament is more important for the doctrine of sanctification than that which was first set in the context of laws regarding clean and unclean foods" (Lev. 11: 44-45). But Lev. 20: 7 (laws in ch. 20) is also important for the doctrine of sanctification. Ibid.

51. Translation is from New International Version. Italic is author.

52. Bruce K. Waltke and M. O'Connor, An Introduction to Biblical Hebrew Syntax (Winona Lake, Indiana: Eisenbrauns, 1990), 398. The reason why the translation uses "you shall make yourselves holy" and not "sanctify yourselves" because Hithpael is counterpart of Piel stem. Piel stem (intensive) "expresses the notion of effecting or causing a state corresponding to the basic meaning of the root". For instance: "to be great" in Piel "to make great"; "to break" in Piel "to make (to be) broken"; "to sanctify" in Piel "to make holy". Then, "sanctify yourselves" is same with "you shall make yourselves holy”.

\section{References}

Berkhof, L. 1948. Systematic Theology. Grand Rapids: Eerdmans.

Bourdeau, D. T. 1964. Sanctification or Living Holiness. Battle Creek, MI: Steam.

Garrett, J. L. Jr. 1995. Systematic Theology: Biblical, Historical, and Evangelical. Vol. 2. Grand Rapids: Eerdmans.

Hamilton, V. P. 1982. Handbook on the Pentateuch. Grand Rapids: Baker.

Hardinge, L. 1988. Leviticus: Christ Is All. Boise, ID: Pacific.

Hartley, J. E. 1992. Leviticus (Word Biblical Commentary). Vol. 4. Dallas, TX: Word.

Heslop, W. G. 1975. Lesson From Leviticus. Grand Rapids: Kregel.

Kiš, M. M. 2000. “Christian Lifestyle and Behavior.” In The
Seventh-Day Adventist Bible Commentary, edited by G. W. Reid. Washington, D.C.: Review \& Herald.

Leviticus: Introduction. 1953. The Seventh-Day Adventist Bible Commentary. Edited by F. D. Nichol. Washington, D.C.: Review \& Herald.

Milgrom, J. 2000. Leviticus 17-22. Anchor Bible. Vol. 3A. Garden City, NY: Doubleday.

Naude, J. A. 1997. “qdš.” In New International Dictionary of Old Testament Theology \& Exegesis, edited by W. A. VanGemeren. Grand Rapids: Zondervan.

Owens, J. J. 1990. Analytical Key to the Old Testament, Vol. 1: Genesis-Joshua. Grand Rapids: Baker.

Pink, A. W. 1975. The Doctrine of Sanctification. Swengel, PA: Reiner.

Random House Dictionary of the English Language. 1987. 2nd ed. NY: Random.

Reid, G. W. 2000. "Health and Healing." In The Seventh-Day Adventist Bible Commentary, edited by G. W. Reid. Washington, DC: Review \& Herald.

Sailhamer, J. H. 1992. The Pentateuch as Narrative. Grand Rapids: Zondervan.

Sangster, W. E. 1943. The Path to Perfection: An Examination \& Restatement of John Wesley's Doctrine of Christian Perfection. London: Epworth.

Supplementary Material. 1953. The Seventh-Day Adventist Bible Commentary. Edited by F. D. Nichol. Washington, D.C.: Review \& Herald.

Thomas, W. H. G. 1957. Through the Pentateuch Chapter by Chapter. Grand Rapids: Eerdmans.

Turnbull, M. R. 1926. Studying of the Book of Leviticus. Virginia: Presbyterian Committee of Publications.

Waltke, B. K. and M. O’Connor. 1990. An Introduction to Biblical Hebrew Syntax. Winona Lake, Indiana: Eisenbrauns.

Walton, J. H. and V. H. Matthews. 1997. The IVP Bible Background Commentary: Genesis-Deuteronomy. Illinois: InterVarsity.

Williams, J. R. 1990. Renewal Theology: Salvation, the Holy Spirit, and Christian Living. Vol. 3. Grand Rapids: Zondervan.

Young, R. 1939. Analytical Concordance to the Holy Bible. 8th ed. Guildford: Lutterworth.

\section{Bio}

Milton T. Pardosi, M.A.R., lecturer, Universitas Advent Indonesia, Indonesia; research field: Biblical studies. 